\title{
The First Record of Geryonia proboscidalis (Forskål, 1775), (Cnidaria: Hydrozoa) on the Coasts of Gökçeada, the Aegean Sea, Turkey
}

\author{
Melek Isinibilir ${ }^{1}$ (D), Esin Yüksel ${ }^{1}$ (D), Ozan Güreşen ${ }^{2}$ (i)
}

Cite this article as: Isinibilir, M., Yuksel, E., \& Guresen, O. (2021). The first record of Geryonia proboscidalis (Forskål, 1775), (Cnidaria: Hydrozoa) on the coasts of Gökçeada, the Aegean Sea, Turkey. Aquatic Sciences and Engineering, 36(4), 215-217.

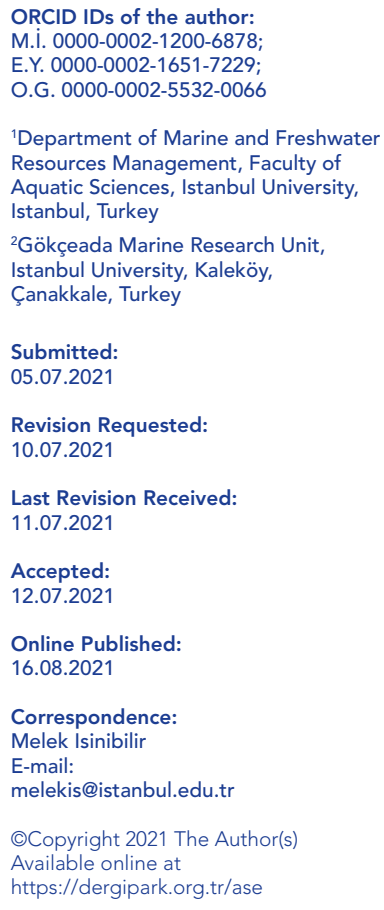

\begin{abstract}
The present study represents the first record of Hydrozoan medusae Geryonia proboscidalis off of Gökçeada island in June 2021. Although this species is found in the Mediterranean, it is the first record specifically in the coastal areas of Gökçeada island. Holidaymakers are extremely irritated by the sting of Geryonia proboscidalis, especially with its sudden accumulation in the coastal areas of Gökçeada island.
\end{abstract}

Keywords: Geryonia proboscidalis, Hydrozoan, Gökçeada, Aegean Sea, holidaymaker

\section{INTRODUCTION}

The island of Gökçeada, with a coastline of 92 $\mathrm{km}$ and a surface area of $279 \mathrm{~km}^{2}$, is the largest island of Turkey and is located in the northeastern Aegean Sea. Especially in summer, the northeast and southwest winds are dominant (Kocataş \& Bilecik, 1992). Also, due to the presence of many nearby islands, water movements in the northern Aegean Sea around Gökçeada show great variation. For example, the Black Sea waters coming from the Çanakkale Strait are directed north in winter and south in summer (Kocataş \& Bilecik, 1992). The water body surrounding the island is enriched with nutrients from the Meriç River (Ulutürk, 1987) and is affected by the colder and less salty water from the Marmara Sea (Kocataş \& Bilecik, 1992).

The class Hydrozoa is a diverse taxon with a wide variety of prey preferences and with more than 3800 species, the majority of which are pelagic and benthic predators (Bouillon, Gravili, Pagès, Gili, \& Boero, 2006). Hence, they are an important component of marine ecosystems, and their bloom may cause significant effects. Regular monitoring may help awareness of new species introductions and/or unpredicted blooms over time (e.g., İşinibilir, Ulucam, \& Yüksel, 2019; Marambio et al., 2021). The jellyfish Geryonia proboscidalis (Forskål, 1775) is a holoplanktonic species belonging to the order Trachymedusae. G. proboscidalis is distributed in the Atlantic, Indo-Pacific, and Mediterranean and prefers warm waters, living in the surface areas of tropical and subtropical seas (Vanucci, 1957). G. proboscidalis has previously been recorded in Boncuk Bay, (Aegean Sea), in Iskenderun Bay (Mediterrenean Sea) and in Sığacık Bay (Aegean Sea) respectively on the coasts of Turkey (Gülşahin, Tarkan, \& Bilge, 2013; Ergüden, Turan, Çevik, \& Uygur, 2014; Akçınar, 2017). The present study indicates that the distribution of $G$. proboscidalis is spreading northerly. In this study, we report on an exceptionally high density of $G$. proboscidalis off the coasts of Gökçeada, in the north Aegean Sea. The study aimed to report the first record of $G$. proboscidalis, with the associated impact on holidaymakers on the Gökçeada island.

\section{MATERIALS AND METHODS}

Geryonia proboscidalis (Forskål, 1775) were observed and sampled on $24^{\text {th }}, 26^{\text {th }}$ and $29^{\text {th }}$ June 2021 in different areas (Yıldız Bay (Yıldızkoy), 
Kaleköy, Kuzulimanı, Mavi Bay (Mavikoy) and Balık Çiftliği respectively) in the northeastern part of the island (Figure 1) while snorkeling and then they were preserved in formaldehyde for identification in the laboratory. The jellyfish were identified referencing the proper literature (Bouillon et al., 2004). Physico-chemical parameters were measured with a multi-probe system in surface water.

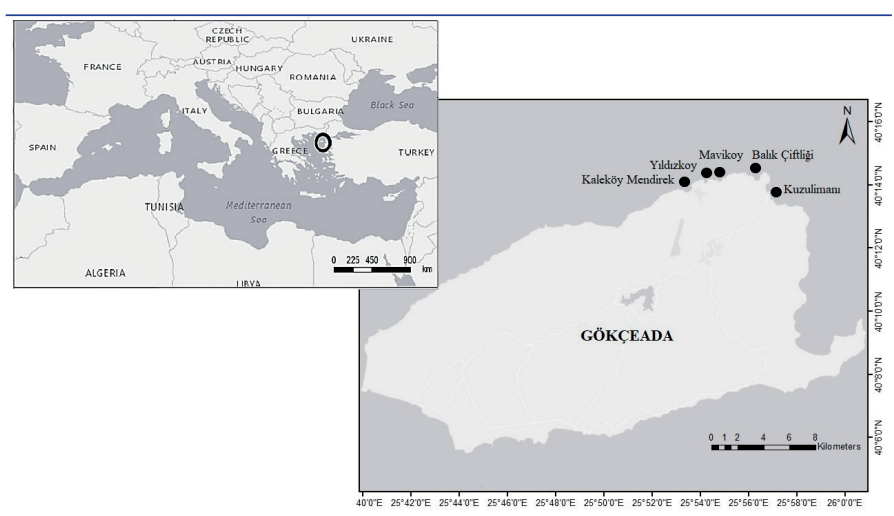

Figure 1. The sampling and observation locations of Geryonia proboscidalis in Gökçeada island.

\section{RESULTS AND DISCUSSION}

The presence of this jellyfish was first discovered in Yıldız Bay during the afternoon of the $24^{\text {th }}$ of June 2021 across the island thanks to the complaints of holidaymakers. They stated that they had swum in Yıldız Bay on the morning of the same day, but they had not experienced any burning or itching. The first theory was that it was caused by dense mucilage aggregation, which was observed in the Marmara Sea in January 2021 and on the coast of Gökçeada island in May 2021. However, when the water samples were taken and examined in the laboratories of Gökçeada Marine Research Unit, it was identified as trachymedusae Geryonia proboscidalis. In the following days, similar complaints came from holidaymakers who went in the sea on the beaches of Kuzulimanı and Kaleköy. Samples were also taken from these regions and underwater photography was taken of the jellyfish accumulation (Figure 2B). Approximately 30 people were hospitalized in Gökçeada island with complaints of redness, itching, and burning all over the body, especially on the arms and neck (Dr. Özlem Çırpan, personal communication). Similar disturbances and events were also occurring in Küçükkuyu, Edremit Bay between 17-26 ${ }^{\text {th }}$ June 2021 (Yazgülü Turan, personal communication). The presence of this species in the northern part of the Aegean Sea may be caused by warmer seawater because of climate change or transportation via water currents.

The highest water temperature in the sampling areas was observed as $30.6^{\circ} \mathrm{C}$ and salinity was $34.8 \mathrm{ppt}$. The umbrella diameters of the Geryonia proboscidalis (Figure 2A) varied between 3-9 $\mathrm{mm}$ wide and were hemispherical with a tiny manubrium on a long, conical gastric peduncle. The mouth has 6 lips; there are up to seven centripetal canals between the radial canals; and the gonads are heart-shaped and quite broad above. It has 12 statocysts, 6 long perradial hollow tentacles with cnidocyst rings, and 6 little solid interradial tentacles with adaxial cnidocyst clusters.

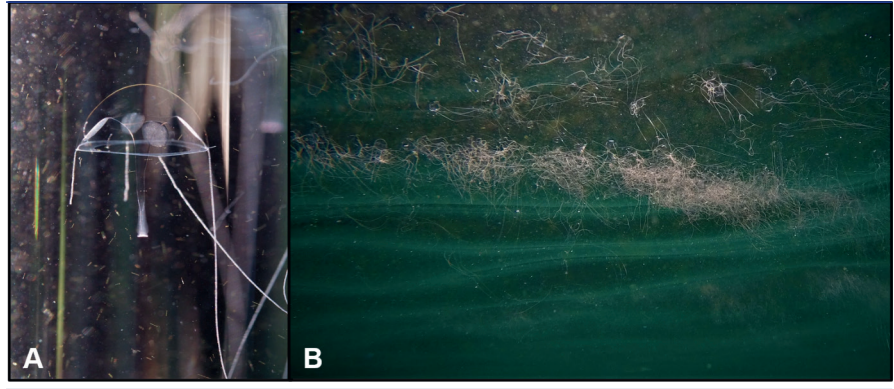

Figure 2. Live specimen (A) and the accumulation (B) of Geryonia proboscidalis in Yıldız Bay, Gökçeada (Photograph: Saadettin Aşkın).

Consequently, the aggregation of $G$. proboscidalis observed in the different coastal areas of Gökçeada was an apparent bloom and was concentrated at one coastal location due to strong winds/ currents, transporting them to the coast. The number of new records of Hydrozoa species in the Aegean Sea coast of Turkey has increased in recent years (Gülşahin et al., 2013; Isinibilir, Martell, Topçu, Yilmaz, \& Piraino, 2015; Yilmaz, Martell, Topcu, \& Isinibilir, 2020). The hydrozoa species diversity in Gökçeada was found to include 48 species (Isinibilir et al., 2015). G. proboscidalis is a new record from the coasts of Gökçeada island. The species has an important ecological role due to its general ability to feed upon fish eggs and larvae and to feed on the plankton that fish larvae consume. They are therefore potential predators and competitors of commercial species. Furthermore, holidaymakers are extremely irritated by the sting of $G$. proboscidalis (Castellani \& Edwards, 2017). Therefore, the occurrence of $G$. proboscidalis, may cause severe effects on public health and tourism in Gökçeada island.

Conflicts of interest: The authors have no conflicts of interest to declare.

Ethics committee approval: The authors declare that this study does not include any experiments with human or animal subjects.

\section{Funding: -}

Acknowledgement: The authors are grateful to underwater photographer Saadettin Aşkın and Chief Doctor of Gökçeada State Hospital Dr. Özlem Çırpan for their valuable contributions.

\section{Disclosure: -}

\section{REFERENCES}

Akçınar, S. C. (2017). In situ predation of Boops boops (Linnaeus, 1758) on the rare hydrozoan, Geryonia proboscidalis (Forsskål, 1775), in the Aegean Sea, Turkey. Turkish Journal of Agriculture-Food Science and Technology, 5(11), 1350-1352. [CrossRef]

Bouillon, J. Gravili, C. Pagès, F. Gili, J. M. \& Boero, F. (2006). An Introduction to Hydrozoa (P. Grandcolas, J.-M. Betsch, P. Bouchet, C. Erard, Eds.). Paris: Mémoires du Muséum d'Histoire Naturelle.

Bouillon, J. Medel, M. D. Pagès, F. Gili, J. M. Boero, F. \& Gravili, C. (2004). Fauna of the Mediterranean hydrozoa. [CrossRef]

Castellani, C. \& Edwards, M. (Eds.). (2017). Marine Plankton: A practical guide to ecology, methodology, and taxonomy. Oxford University Press. [CrossRef] 
Ergüden, D. Turan, C. Cevik, C. \& Uygur, N. (2014). First occurrence of the hydrozoan Geryonia proboscidalis (Forskål, 1775) in the northeastern Mediterranean coast of Turkey. J. Black Sea/Mediterranean Environment, 20(2), 147-151.

Gülşahin, N. Tarkan, A. N. \& Bilge, G. (2013). The hydrozoan Geryonia proboscidalis (Forskål, 1775), new for Turkey (Hydrozoa). Zoology in the Middle East, 59(1), 93-94. [CrossRef]

Isinibilir, M. Martell, L. Topçu, E. N. Yilmaz, I. N. \& Piraino, S. (2015). First inventory of the shallow-water benthic hydrozoan assemblages of Gökçeada Island (northern Aegean Sea). Italian Journal of Zoology, 82(2), 281-290.

İşinibilir, M. Ulucam, K. \& Yüksel, E. (2019). First record of Physophora hydrostatica Forskål, 1775 (Cnidaria, Hydrozoa) for the Turkish seas. Journal of the Black Sea/Mediterranean Environment, 25(2).

Kocataş, A. \& N. Bilecik. (1992). Aegean Sea and its living Resources. (in Turkish). Bodrum Su Ürünleri Araştırma Enstitüsü Yayınları. Ser. A, No 7, $88 \mathrm{pp}$
Marambio, M. Canepa, A. Lòpez, L. Gauci, A. A. Gueroun, S. K. Zampardi, S. \& Deidun, A. (2021). Unfolding jellyfish bloom dynamics along the Mediterranean basin by transnational citizen science initiatives. Diversity, 13(6), 274. [CrossRef]

Ulutürk, T. (1987). Fish Fauna and Environmental Fon Radioactity of Gökçeada Area (in Turkish). i.ü. Su ürünleri Derg. 1(1): 95- 119.

Vannucci, M. (1957). On Brazilian Hydromedusae and their distribution in relation to different water masses. Boletim do Instituto Oceanográfico, 8(1-2), 23-109. [CrossRef]

Yilmaz, I. N. Martell, L. Topcu, N. E. \& Isinibilir, M. (2020). Benthic hydrozoan assemblages as potential indicators of environmental health in a Mediterranean marine protected area. Mediterranean Marine Science 21(1): 36-46. [CrossRef] 